\title{
Design, Synthesis of N-(Substituted Imidazo [1, 2-b] Pyridazine) Acetamides and Their Anti-Proliferative Studies on BRAFV600E Mutated A375 and Colo-205 Cell Lines.
}

\author{
Sruthi $\mathrm{K}^{*}{ }^{1}$, Sumakanth $\mathrm{M}^{1}$, Mahendra Kumar $\mathrm{CB}^{2}$, Naresh $\mathrm{K}^{3}$ \\ ${ }^{1}$ Department of Pharmaceutical Chemistry R.B.V.R.R Women's College of Pharmacy, Osmania University, \\ Hyderabad, India. \\ ${ }^{2}$ Department of Pharmaceutical Analysis, St. Mary's College of Pharmacy, Secunderabad, India. \\ ${ }^{3}$ Department of Pharmaceutical Chemistry, G. Pulla Reddy College of Pharmacy, Osmania University, \\ Hyderabad, India.
}

\begin{abstract}
In the present investigation, a new series of imidazo[1,2-b]pyridazines were designed and synthesized and screened for their anti-proliferative activity. An efficient method is described for the synthesis of $N$-(substituted imidazo [1, 2-b] pyridazine) acetamides that consists of nucleophilic addition of 3-amino pyridazine which raises the electrophilicity of 4-Arylidine-2-methyl-oxazole-5-ones followed by ring opening and cyclization steps. The synthesized compounds were evaluated for their possible anti-proliferative activity in A375 and colo-205 human cancer cell lines by employing MTT assay and most of the compounds were found to be highly active. The most active compounds of the series on both the cell lines were $5 \mathrm{~m}, 5 \mathrm{n}$ with $I C_{50}$ values of $21 \mathrm{nM}, 20 \mathrm{nM}$ on A375 cell lines and $38 \mathrm{nM}, 31 \mathrm{nM}$ on colo-205 cell lines respectively. The title compounds were employed to molecular docking studies to position the molecules into B-Raf Kinase v600E (PDBID: 3IDP) and to determine its binding interactions and the most probable binding sites. The results from the binding energies suggest that the compounds have moderate to strong affinity for the BRAFV600E kinase binding site with G-Scores ranging from -9.2 to -6.9 indicating their potential to be antitumor agents. The title compounds were also subjected to molecular toxicity prediction using OSIRIS property explorer. The results indicated that all the compounds are druggable candidates and are free from toxicity and mutagenicity.
\end{abstract}

Keywords: BRaf kinase, imadazo[1,2-b]pyridazines, anticancer, A375, Colo-205, OSIRIS

\section{Introduction}

Imidazodiazines $^{1}$ are the bicyclic hetero compounds containing diazines fused across 1,2-bond of imidazole. The structural resemblance of imidazodiazine ring skeleton with purines has attracted considerable interest to assess potential therapeutic activities. As the pivotal role of purines in numerous diseases ${ }^{2,3,4}$ were already known and hence in the present investigation imidazopyridazines have been considered as the important structural frame work.Although, Various methods ${ }^{5,6,7}$ have been reported to assemble imidazole around pyridazine, the present synthetic route establishes a distinct entry into imidazopyridazines by the ring opening of 4-Arylidine-2-methyl oxazolones with 3-amino substituted pyridazines. The route offers significant flexibility to access these important heteroaromatic frameworks with unexplored and/or otherwise challenging substitution patterns. Imidazopyridazines consists of various isomeric forms, imidazo[1,2-b]pyridazines, imidazo[4,5c]pyridazines etc. Patents have been filed on various imidazopyridazine derivatives for their antimalarial ${ }^{8}$, antihypertensive ${ }^{9}$,antifunga ${ }^{10}$, antiinflammarory ${ }^{11}$ and anticancer activities ${ }^{12,13,14}$. Some new molecules were also entered in various phases of clinical trials. The above facts prompted us to take a look at the design and synthesis of various imidazopyridazines and to explore and compare their potency as possible Raf kinase inhibitors. The Raf kinases are the regulatory proto-oncogenes that play a significant role mitogen-activated protein kinase/extracellular-signal-regulated kinase (MAPK/ERK) pathway ${ }^{15}$ which is a signalling module that connects cell-surface receptors and Ras proteins to nuclear transcription factors. Indeed, the pathway is deregulated in $30 \%$ of all human tumours including prevalent cancers of the colon and lung. A variety of agents have been discovered to interfere with Raf kinase, including antisense oligonucleotides and small molecules. Raf inhibitors that are currently undergoing clinical evaluation show promising signs of anti-cancer efficacy with a well established safety profile and among them, BAY 43-9006 is clinically most advanced Raf inhibitor, which recently entered phase III clinical testing. 


\section{Materials And Methods}

Synthetic grade solvents and all the chemicals used were of synthetic grade obtained from SD fine chemicals, Merck and Sigma Aldrich. The solvents received from vendors were purified as per the prescribed methods and used for the synthesis. Reactions were monitored by using pre-coated Silica Gel TLC plates and the spots were visualised under UV light and in iodine chamber. The synthesized compounds were purified by recrystallization and purity was determined by measuring in Kofler hot stage melting point apparatus and are uncorrected. The IR spectrums were recorded on Shimadzu FTIR spectrophotometer by using 1\% KBR discs. Proton NMR was recorded on Bruker Avance II $400 \mathrm{MHz}$ NMR spectrophotometer with TMS as internal standard mass spectrum was recorded using Agilent 1100. Elemental analysis was determined in Carlo Erba 1108 elemental analyzer and compared with the calculated data.

\subsection{Synthesis}

\section{Results And Discussion}

The synthesis of $\mathrm{N}$-(3-aryl -2-oxo-2,3-dihydro imidazo[1,2-b]pyridazine) acetamide 5a-5n was achieved from the synthetic route depicted in figure 3. The Acetyl glycine(1) prepared was treated with various aryl and hetero aryl aldehydes to obtain 4-Arylidine-2-methyl-Oxazole-5-Ones(2a-2n), the reaction progress was monitored by TLC and the formation of the compounds was confirmed by melting point and spectral data. The IR spectra of 4-Benzylidine-2-methyl-Oxazole-5-One (2a) showed the characteristic absorption peak at $1155 \mathrm{~cm}^{-1}$ corresponds to C-O-C stretching, which confirms the formation of compound 2a. In the next step each of the 4-Arylidine-2-methyl-Oxazole-5-One (2a-2n) was made to react with 3-amino pyridazine in ethylene glycol at $120^{\circ} \mathrm{C}$ to yield the corresponding $\mathrm{N}$-(3-substituted 2-oxo-2,3-dihydro imidazo $[1,2-b]$ pyridazine acetamides $(\mathbf{5 a}-\mathbf{5 n})$ All the compounds were obtained in good yields and were characterised by melting point, proton NMR, FTIR and mass spectral data. The elemental analyses of the compounds were determined and were comparable with the calculated values. The reaction was initiated by the nucleophilic attack of 3-amino pyridazine onto the carbonyl carbon of 4-Arylidine-2-methyl-Oxazole-5-One followed by ring opening through the $\mathrm{C}-\mathrm{O}$ bond of the heterocyclic oxazole ring and further the reaction ends up with the cyclization of the molecule to yield $\mathrm{N}$-(3-substituted 2-oxo-2,3-dihydro imidazo[1,2-b]pyridazine acetamide (5a-5n). The formation of title compounds was confirmed by FTIR with the characteristic NH peak at $3330 \mathrm{~cm}^{-1}$ and carbonyl peak at $1681 \mathrm{~cm}^{-1}$, the characteristic singlet of NH proton at $\delta 9.71$ and another characteristic $-\mathrm{CH}_{2}$ singlet at $\delta 3.41$ were observed in proton NMR spectra.

\subsection{Anti Proliferative Studies}

The synthesized $\mathrm{N}$-(3-aryl -2-oxo-2,3-dihydro imidazo[1,2-b]pyridazine) acetamides 5a-5n were evaluated for the antiproliferative activity on human cancer cell lines A375(Melanoma) and Colo205(Colorectal) by using MTT assay in 346 well microtiter plates, the detailed procedure described in our earlier publication ${ }^{16}$. The expression of BRAFV600E kinase is the common criteria and rationale for selecting these cell lines. In this in vitro study dabrafenib was taken as a standard drug to compare the activity of test compounds. Control plates containing DMSO were also maintained to determine the growth inhibitory concentration. The in vitro activity of each of the compound was studied at final concentrations ranging from $0.1 \mathrm{nM}$ to $10 \mu \mathrm{M}$. The results of the test showed (TABLE 1) that compounds $5 \mathrm{a}-5 \mathrm{n}$ was found to be active against both of the cell lines. However, the inhibitory potency was found to be more on A375 cell lines than the colo-205. Compounds carrying indole nucleus $5 \mathrm{~m}$ and $5 \mathrm{n}$ were found to be highly active on both the cell lines with $\mathrm{IC}_{50}$ values $21 \mathrm{nM}$ and $20 \mathrm{nM}$ on A375, $38 \mathrm{nM}$ and $31 \mathrm{~nm}$ on colo-205 cell lines respectively. However the imidazo[1,2-b]pyridazine acetamides carrying $4-\mathrm{OH}$ on phenyl ring (5d) and $4-\mathrm{NH}_{2}$ on phenyl ring (5h) were also found to be potent on $\mathrm{A} 375$ cell lines with $\mathrm{IC}_{50}$ of $36 \mathrm{nM}$ and $24 \mathrm{nM}$ respectively. Compounds $5 \mathrm{~g}, 5 \mathrm{i}, 5 \mathrm{k}$ and 51 were exhibited remarkable inhibition on the growth of A375 cell lines with $\mathrm{IC}_{50}$ values $56 \mathrm{nM}, 86 \mathrm{nM}, 79$ $\mathrm{nM}$ and $55 \mathrm{nM}$ respectively, whereas on colo-205 cell lines compound $5 \mathrm{~g}\left(\mathrm{IC}_{50} 25 \mathrm{nM}\right)$ was found to be more active. Compound $5 \mathrm{c}$ and $5 \mathrm{j}$ were found to be weakly active on colo-205. Apparently, all the remaining compounds were demonstrated moderate anti-proliferative activity on the A375, Colo-205 cell lines. It was evident from the above results that the synthesized N-(3-aryl -2-oxo-2,3-dihydro imidazo[1,2-b]pyridazine) acetamides could be active against the melanoma and colorectal cancers involving BRAFV600E kinase. Hence, in the therapeutic grounds these compounds are considered as the potent anti cancer molecules inhibit BRAF kinases. 
Table 1: Antiproliferative activity results of N-(3-substituted -2-oxo-2,3-dihydro imidazo $[1,2-b]$ pyridazine)acetamides $5 \mathrm{a}-5 \mathrm{n}$

\begin{tabular}{|c|c|c|}
\hline Compound & IC $_{\mathbf{5 0}}$ value (nM) A375 & IC $_{\mathbf{5 0}}$ value (nM) Colo-205 \\
\hline $5 \mathrm{a}$ & 325 & 550 \\
\hline $5 \mathrm{~b}$ & 400 & 980 \\
\hline $5 \mathrm{c}$ & 425 & $>1000$ \\
\hline $5 \mathrm{~d}$ & 36 & 150 \\
\hline $5 \mathrm{e}$ & 150 & 250 \\
\hline $5 \mathrm{f}$ & 120 & 865 \\
\hline $5 \mathrm{~g}$ & 56 & 25 \\
\hline $5 \mathrm{~h}$ & 24 & 76 \\
\hline $5 \mathrm{i}$ & 86 & 258 \\
\hline $5 \mathrm{j}$ & 157 & $>1000$ \\
\hline $5 \mathrm{k}$ & 79 & 120 \\
\hline $5 \mathrm{sm}$ & 55 & 98 \\
\hline $5 \mathrm{~m}$ & 21 & 38 \\
\hline $5 \mathrm{n}$ & 20 & 31 \\
\hline Dabrafenib & 5 & 8 \\
\hline
\end{tabular}

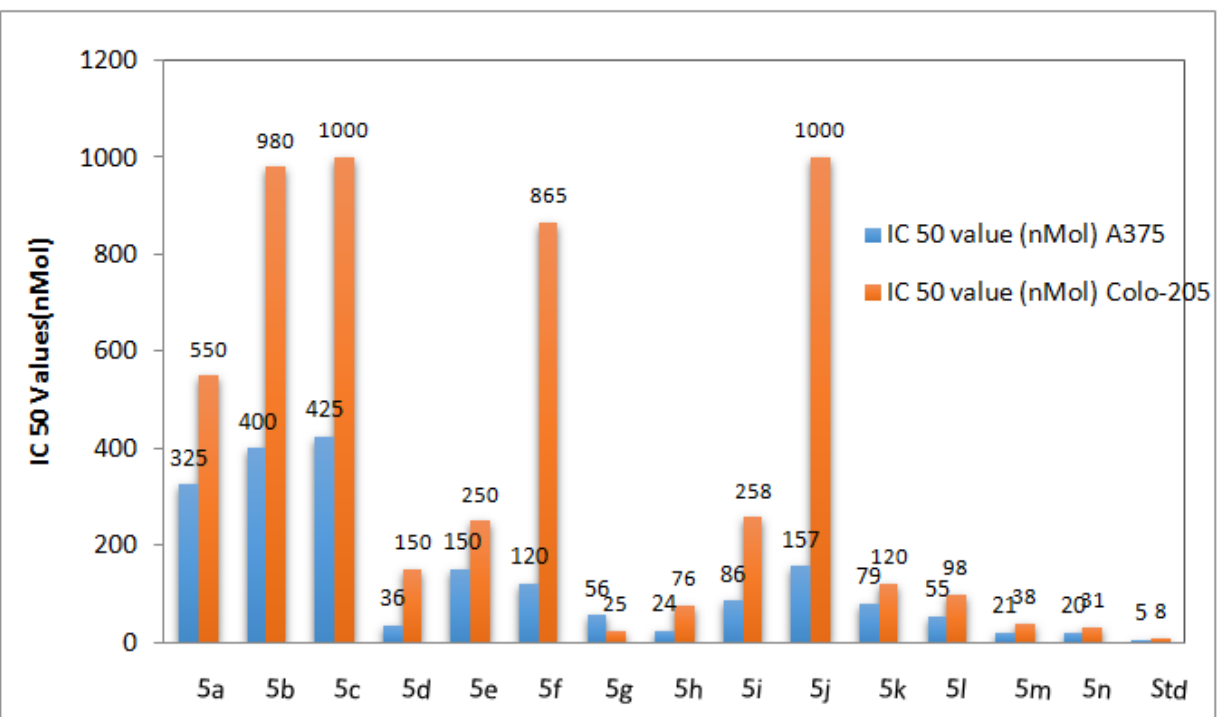

Figure 1: In vitro anticancer activity of Imidazo $[1,2-b]$ pyridazine acetamides $5 a-5 n$

Table 2. Molecular properties and Toxicity prediction by OSIRIS

\begin{tabular}{|c|c|c|c|c|c|c|c|c|}
\hline $\begin{array}{l}\text { Molecule } \\
\text { Name }\end{array}$ & $\begin{array}{l}\text { Total } \\
\text { Molweight }\end{array}$ & $c \log P$ & cLogS & H-Acceptors & H-Donors & $\begin{array}{l}\text { Polar } \\
\text { Surface Area }\end{array}$ & Drug likeness & $\begin{array}{l}\text { Rotatable } \\
\text { Bonds }\end{array}$ \\
\hline $5 \mathrm{~A}$ & 282.302 & 0.4547 & -2.31 & 6 & 1 & 74.13 & 3.3534 & 3 \\
\hline $5 B$ & 316.747 & 1.0607 & -3.046 & 6 & 1 & 74.13 & 3.3992 & 3 \\
\hline $5 \mathrm{C}$ & 361.198 & 1.1799 & -3.144 & 6 & 1 & 74.13 & 1.5634 & 3 \\
\hline $5 \mathrm{D}$ & 298.301 & 0.109 & -2.014 & 7 & 2 & 94.36 & 3.3642 & 3 \\
\hline $5 \mathrm{E}$ & 298.301 & 0.109 & -2.014 & 7 & 2 & 94.36 & 3.3642 & 3 \\
\hline $5 \mathrm{~F}$ & 296.329 & 0.7986 & -2.654 & 6 & 1 & 74.13 & 3.3534 & 3 \\
\hline $5 \mathrm{G}$ & 312.328 & 0.3847 & -2.328 & 7 & 1 & 83.36 & 3.3882 & 4 \\
\hline $5 \mathrm{H}$ & 297.317 & -0.2226 & -2.386 & 7 & 2 & 100.15 & 3.3438 & 3 \\
\hline $5 \mathrm{I}$ & 332.362 & 1.6491 & -3.916 & 6 & 1 & 74.13 & 3.3534 & 3 \\
\hline $5 \mathrm{~J}$ & 271.279 & -0.8228 & -1.334 & 7 & 2 & 89.92 & 3.4401 & 3 \\
\hline $5 \mathrm{~K}$ & 283.29 & -0.5462 & -1.515 & 7 & 1 & 87.02 & 3.3534 & 3 \\
\hline $5 \mathrm{~L}$ & 272.263 & -0.4106 & -1.968 & 7 & 1 & 87.27 & 3.1629 & 3 \\
\hline $5 \mathrm{M}$ & 321.339 & 0.4941 & -2.835 & 7 & 2 & 89.92 & 3.4401 & 3 \\
\hline $5 \mathrm{~N}$ & 400.235 & 1.2193 & -3.669 & 7 & 2 & 89.92 & 1.6501 & 3 \\
\hline
\end{tabular}

\subsection{Molecular docking studies}

The structures of all the synthesized $\mathrm{N}$-(3-aryl -2-oxo-2,3-dihydro imidazo [1,2-b]pyridazine) acetamides 5a-5n were docked into the binding site of BRAFV600E kinase (PDBID: 3IDP) using AUTODOCK 4.2.6 software in order to assess the ability of the compounds. The detailed procedure was described in our recent publication ${ }^{16,17}$. The $2 \mathrm{D}$ structures were prepared in chemdraw and their pdb files were prepared using 
PRODRG server. Later, the pdbqts of all the ligands and target protein were generated in autodock. These pdbqts were used to assign grid parameters and docking parameters in the docking study. The gpf files were prepared for each ligand contained grid parameters that locates the binding site within the target protein. Docking parameters were assigned to the software default values and docking was carried out for each of the ligand in the series using Lamarckian Genetic Algorithm. After docking, the binding energies for each of the ligands were considered to assess the binding affinity of the ligands. The binding interactions of the each of the ligand with the BRAF kinase were studied.

The molecular docking results showed that compounds $5 \mathrm{~m}, 5 \mathrm{n}$ have good binding affinity within the active site of B-Raf kinase with a binding energy of $-8.9 \mathrm{~K}$.Cal $/$ mole and $-9.6 \mathrm{~K} . \mathrm{Cal} / \mathrm{mole}$ respectively(Fig 2 ). Indole $-\mathrm{NH}$ of the compound $5 \mathrm{~m}$ interacts with Glu-501 by means of $\mathrm{H}$-bond $\left(1.949 \mathrm{~A}^{\circ}\right)$. Indole ring also forms hydrophobic interactions with Leu-514, Gly-593 and Asp-594. The imidazopyridazine ring is in close proximity to Cys-532, Trp-531. The acetamido portion of the compound made polar interactions with Thr-529, Val-482, Lys-483.In Compound 5n, the imidazopyridazine ring interacts with Lys-483, Glu-501, Ala-481. The C=O at second Position of the ring forms polar contacts with Gly-593 and Asp-594.whereas Compound 5h forms a Hbond with Leu-514 $\left(2.77 \mathrm{~A}^{\circ}\right)$ and the aromatic ring is embedded within the aminoacids Ile-513, Ile-592. The imidazopyridazine ring is also in close proximity to Lys-483, Thr-529. Lys-483 also forms polar interaction with $\mathrm{NH}$ of acetamide. Interestingly, Compound 5d with binding energy $-7.97 \mathrm{~K} . \mathrm{Cal} / \mathrm{mole}$ showed remarkable interactions with target protein. The hydroxyl group of this compound forms H-bond with Cys-532(2.067 $\left.\mathrm{A}^{\circ}\right)$. Another H-bond with Trp-531 $\left(2.245 \mathrm{~A}^{\circ}\right)$. The imidazopyridazine ring also forms hydrophobic interactions with Phe-595. The phenyl ring interacts with Thr-529,Gln-513 and Leu-514 whereas the acetamide group interacts with Lys-483. The binding interactions of title compounds were well correlated with the binding modes of the standard B-Raf v 600E kinase inhibitor, Dabrafenib( K.Cal/mole).
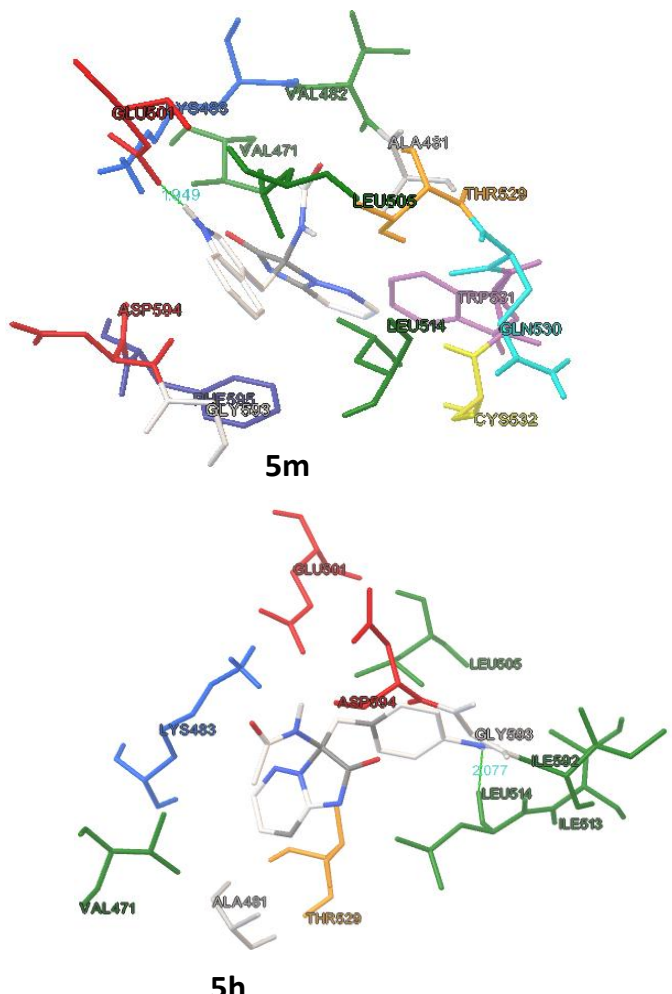

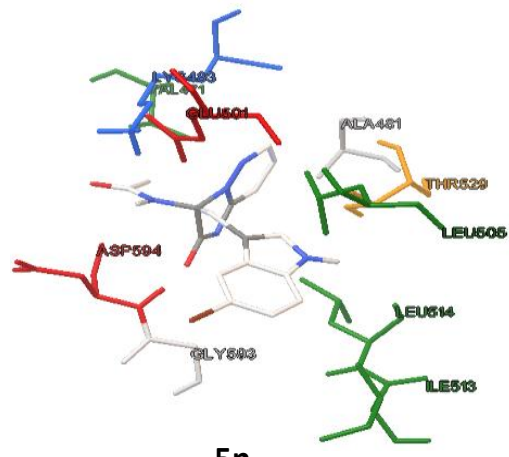

$5 n$

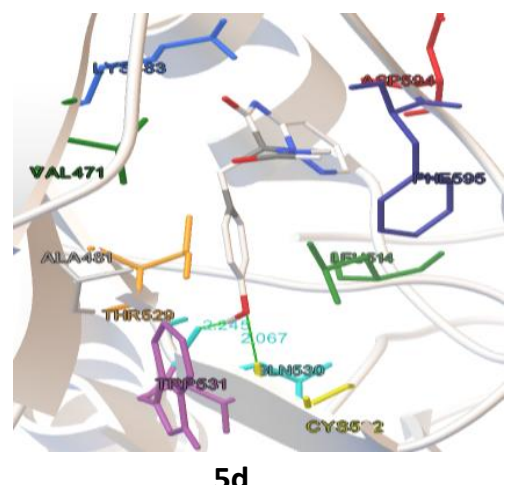

5d

Figure 2. Binding interactions of compounds $5 \mathrm{~m}, 5 \mathrm{n}, 5 \mathrm{~h}, 5 \mathrm{~d}$ within the binding site of B-Raf v600 E kinase(PDB ID : 3IDP)

\subsection{Molecular properties and toxicity prediction}

The molecular properties of the synthesized compounds such as $\log \mathrm{P}, \log \mathrm{S}$, number of hydrogen bond donors, hydrogen bond acceptors, polar surface area, number of rotatable bonds, drug likeness were predicted using OSIRIS molecular properties explorer ${ }^{16}$ and the data is presented in TABLE 2 . In this prediction all the compounds were found to obeyed Lipinski rule of five, which suggests that these compounds could be druggable candidates. Interesting facts were uncovered when polar surface area, number of hydrogen bond donors and hydrogen bond acceptors were related with the in vitro anti-proliferative activity of the compounds. Compounds which exhibited highest activity, possesses 7HBD, 2 HBA and the polar surface area was between 
89-100. Thus, these properties could be helpful to explain the mechanism of action of the compounds in support to in vitro and molecular docking studies. The toxicity prediction of the compounds revealed that all the compounds were potentially non toxic and devoid of mutagenicity and tumorigenicity.

\section{Experimental}

\subsection{Synthesis $N$-(3-substituted 2-oxo-2,3-dihydro imidazo[1,2-b]pyridazine acetamides}

\subsubsection{General procedure for the synthesis of 4-Arylidene-2-methyl oxazole-5(4H)-ones (2a-2n)}

The step by step procedures involved in the synthesis of 4-Arylidene-2-methyl oxazole-5(4H)-ones $(2 \mathrm{a}-2 \mathrm{n})$ was same as described in our earlier publications ${ }^{16}$ or unless otherwise stated. Herein we report the same in brief, equimolar $(0.25 \mathrm{~mol})$ concentration of acetyl glycine were heated on electrical hot plate with occasional shaking inorder to get a clear solution. This hot solution was immediately transferred to a round bottomed flask and refluxed for $2 \mathrm{hrs}$. Later, $100 \mathrm{ml}$ of ethanol was added to the reaction mixture and was kept at room temperature for overnight. The crude crystalline compound was collected and washed with Ice cold ethanol followed by boiling water.

\subsubsection{Synthesis of $\mathrm{N}$-(3-substituted 2-oxo-2,3-dihydro imidazo[1,2-b]pyridazine acetamides(5a-5n)}

4-Arylidene 2-methyl oxazole-5(4H)-one $2 \mathrm{a}-2 \mathrm{n}(0.001 \mathrm{~mol})$ and 3 -Amino pyridazine $(0.001 \mathrm{~mol})$ were transferred to flask containing ethylene glycol $(5 \mathrm{ml})$ and refulx to $120^{\circ} \mathrm{C}$. The completion of the reaction and formation of the compound was monitored by TLC. After confirmation by TLC the reaction mixture was cooled to room temperature and then poured into beaker containing $50-75 \mathrm{ml}$ water and filtered to collect the product. The product was recrystallized from ethanol. All the compounds synthesized were purified and the structures were further characterized by spectral and elemental analysis.

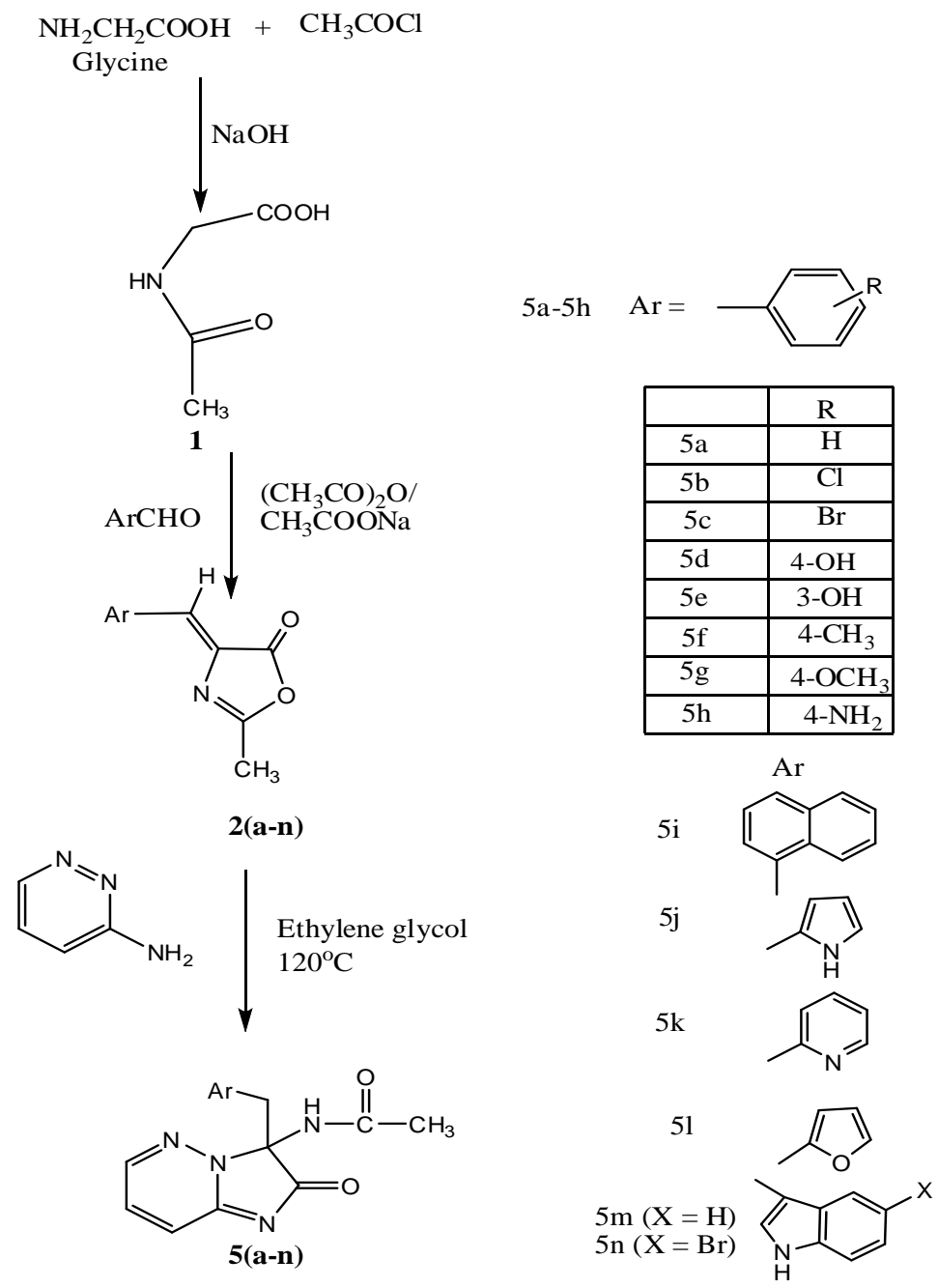

Figure 3. Scheme to obtain N-(3-substituted 2-oxo-2,3-dihydro imidazo[1,2-b]pyridazine acetamides $(5 \mathrm{a}-5 \mathrm{n})$ 
Design, Synthesis Of N-(Substituted Imidazo [1,2-b]Pyridazine) Acetamides And Their Anti-

\section{N-(3-benzyl-2-oxo-2,3-dihydroimidazo[1,2-b]pyridazin-3-yl)acetamide(5a)}

$\%$ Yield: 74\%, $\mathrm{mp}\left({ }^{\circ} \mathrm{C}\right):-178-180, \mathrm{IR}(\mathrm{KBr}) \quad(\mathrm{cm}-1): \quad 3325(\mathrm{NH}) ; 2926(\mathrm{CH}), 1684(\mathrm{C}=\mathrm{O}),{ }^{1} \mathrm{H}$ NMR (DMSO) $\delta(\mathrm{ppm}): 9.72(\mathrm{~s}, 1 \mathrm{H}, \mathrm{NH}), 7.26-7.58(\mathrm{~m}, 5 \mathrm{H}, \mathrm{ArH}), 7.24(\mathrm{t}, 2 \mathrm{H}, \mathrm{IPArH}), 7.90(\mathrm{~d}, 1 \mathrm{H}, \mathrm{IPArH})$ 3.45(s, $\left.2 \mathrm{H},-\mathrm{CH}_{2}\right), 2.2\left(\mathrm{~s}, 3 \mathrm{H},-\mathrm{CH}_{3}\right)$, MS m/z: $282(\mathrm{M}+)$, Anal. calcd. (\%) for: $\mathrm{C}_{15} \mathrm{H}_{14} \mathrm{~N}_{4} \mathrm{O}_{2}: \mathrm{C}, 63.82 ; \mathrm{H}$, $5.00 ; \mathrm{N}, 19.85 ; \mathrm{O}, 11.34$, found: $\mathrm{C}, 63.79 ; \mathrm{H}, 5.12 ; \mathrm{N}, 19.82 ; \mathrm{O}, 11.36$.

N-(3-(4-chlorobenzyl)-2-oxo-2,3-dihydroimidazo[1,2-b]pyridazin-3-yl)acetamide (5b)

\% Yield: 68\%, $\mathrm{mp}\left({ }^{\circ} \mathrm{C}\right): 188-190, \operatorname{IR}(\mathrm{KBr}) \vee(\mathrm{cm}-1): 3324(\mathrm{NH}) ; 2936(\mathrm{CH}), 1681(\mathrm{C}=\mathrm{O}),{ }^{1} \mathrm{H}$ NMR (DMSO) $\delta(\mathrm{ppm}): 9.75(\mathrm{~s}, 1 \mathrm{H}, \mathrm{NH}), 7.32-7.67(\mathrm{~m}, 4 \mathrm{H}, \mathrm{ArH}), 7.22(\mathrm{t}, 2 \mathrm{H}, \mathrm{IPArH}), 8.10(\mathrm{~d}, 1 \mathrm{H}, \mathrm{IPArH})$ 3.44(s, $\left.2 \mathrm{H},-\mathrm{CH}_{2}\right), 2.1\left(\mathrm{~s}, 3 \mathrm{H},-\mathrm{CH}_{3}\right), \mathrm{MS} \mathrm{m} / \mathrm{z}: 316(\mathrm{M}+)$, Anal. calcd. (\%) for: $\mathrm{C}_{15} \mathrm{H}_{13} \mathrm{ClN}_{4} \mathrm{O}_{2}: \mathrm{C}, 56.88$; $\mathrm{H}, 4.14 ; \mathrm{Cl}, 11.19 ; \mathrm{N}, 17.69 ; \mathrm{O}, 10.10$, found: $\mathrm{C}, 56.86 ; \mathrm{H}, 4.16 ; \mathrm{Cl}, 11.21 ; \mathrm{N}, 17.71 ; \mathrm{O}, 10.10$

N-(3-(4-bromobenzyl)-2-oxo-2,3-dihydroimidazo[1,2-b]pyridazin-3-yl)acetamide (5c)

$\%$ Yield: $71 \%, \operatorname{mp}\left({ }^{\circ} \mathrm{C}\right): 184-186, \mathrm{IR}(\mathrm{KBr}) \mathrm{v}(\mathrm{cm}-1)$ : $3325(\mathrm{NH}) ; 2926(\mathrm{CH}), 1682(\mathrm{C}=\mathrm{O}),{ }^{1} \mathrm{H}$ NMR (DMSO) $\delta(\mathrm{ppm}): 9.74(\mathrm{~s}, 1 \mathrm{H}, \mathrm{NH}), 7.35-7.61(\mathrm{~m}, 4 \mathrm{H}, \mathrm{ArH}), 7.24(\mathrm{t}, 2 \mathrm{H}, \mathrm{IPArH}), 8.01(\mathrm{~d}, 1 \mathrm{H}, \mathrm{IPArH})$ 3.45(s, $\left.2 \mathrm{H},-\mathrm{CH}_{2}\right), 2.2\left(\mathrm{~s}, 3 \mathrm{H},-\mathrm{CH}_{3}\right), \mathrm{MS} \mathrm{m} / \mathrm{z}: 361(\mathrm{M}+)$, Anal. calcd. (\%) for: $\mathrm{C}_{15} \mathrm{H}_{13} \mathrm{BrN}_{4} \mathrm{O}_{2}: \mathrm{C}, 49.88$; $\mathrm{H}, 3.63 ; \mathrm{Br}, 22.12 ; \mathrm{N}, 15.51 ; \mathrm{O}, 8.86$, found $\mathrm{C}, 49.90 ; \mathrm{H}, 3.60 ; \mathrm{Br}, 22.13 ; \mathrm{N}, 15.49 ; \mathrm{O}, 8.89$

N-(3-(4-bromobenzyl)-2-oxo-2,3-dihydroimidazo[1,2-b]pyridazin-3-yl)acetamide(5d)\% Yield: 65 $\%, \mathrm{mp}\left({ }^{\mathrm{O}} \mathrm{C}\right): 156-160, \mathrm{IR}(\mathrm{KBr}) \mathrm{v}(\mathrm{cm}-1): 3326(\mathrm{NH}) ; 2928(\mathrm{CH}), 1681(\mathrm{C}=\mathrm{O}),{ }^{1} \mathrm{H}$ NMR (DMSO) $\delta$ (ppm): 9.71(s,1H,NH), 7.20-7.50(m, 4H, ArH),7.20(t, 2H, IPArH), 7.80(d, 1H, IPArH), 4.9(s, 1H, $\mathrm{OH}), 3.32\left(\mathrm{~s}, 2 \mathrm{H},-\mathrm{CH}_{2}\right), 2.1\left(\mathrm{~s}, 3 \mathrm{H},-\mathrm{CH}_{3}\right) \mathrm{MS} \mathrm{m} / \mathrm{z}: 298(\mathrm{M}+)$, Anal. calcd. (\%) for: $\mathrm{C}_{15} \mathrm{H}_{14} \mathrm{~N}_{4} \mathrm{O}_{3}: \mathrm{C}$, $60.40 ; \mathrm{H}, 4.73 ; \mathrm{N}, 18.78 ; \mathrm{O}, 16.09$, found $\mathrm{C}, 60.44 ; \mathrm{H}, 4.71 ; \mathrm{N}, 18.81 ; \mathrm{O}, 16.13$

$\mathrm{N}$-(3-(3-hydroxybenzyl)-2-oxo-2,3-dihydroimidazo[1,2-b]pyridazin-3-yl)acetamide(5e)

$\%$ Yield: 64\%, $\mathrm{mp}\left({ }^{\circ} \mathrm{C}\right)$ : 138-140, IR(KBr) v $(\mathrm{cm}-1)$ : 3329(NH); 2928(CH), 1680(C=O), ${ }^{1} \mathrm{H}$ NMR (DMSO) $\delta$ (ppm): 9.71(s,1H,NH), 7.18-7.52(m, 4H, ArH), 7.20(t, 2H, IPArH), 7.80(d, 1H, IPArH), 4.9(s, $1 \mathrm{H}, \mathrm{OH}), 3.32\left(\mathrm{~s}, 2 \mathrm{H},-\mathrm{CH}_{2}\right), 2.1\left(\mathrm{~s}, 3 \mathrm{H},-\mathrm{CH}_{3}\right), \mathrm{MS} \mathrm{m} / \mathrm{z}: 298(\mathrm{M}+)$, Anal. calcd. (\%) for: $\mathrm{C}_{15} \mathrm{H}_{14} \mathrm{~N}_{4} \mathrm{O}_{3}: \mathrm{C}, 60.38 ; \mathrm{H}, 4.75 ; \mathrm{N}, 18.75 ; \mathrm{O}, 16.12$, found $\mathrm{C}, 60.41 ; \mathrm{H}, 4.72 ; \mathrm{N}, 18.70 ; \mathrm{O}, 16.17$.

\section{$\mathrm{N}$-(3-(4-methylbenzyl)-2-oxo-2,3-dihydroimidazo[1,2-b]pyridazin-3-yl)acetamide(5f)}

$\%$ Yield: $81 \%, \operatorname{mp}\left({ }^{\circ} \mathrm{C}\right): 178-182, \mathrm{IR}(\mathrm{KBr}) \mathrm{v}(\mathrm{cm}-1)$ : $3325(\mathrm{NH}) ; 2926(\mathrm{CH}), 1682(\mathrm{C}=\mathrm{O}),{ }^{1} \mathrm{H}$ NMR (DMSO) $\delta(\mathrm{ppm}): 9.71(\mathrm{~s}, 1 \mathrm{H}, \mathrm{NH}), 7.18-7.53(\mathrm{~m}, 4 \mathrm{H}, \mathrm{ArH}), 7.20(\mathrm{t}, 2 \mathrm{H}, \mathrm{IPArH}), 7.80(\mathrm{~d}, 1 \mathrm{H}, \mathrm{IPArH})$ 3.32(s, 2H,- $\left.\mathrm{CH}_{2}\right), 2.1\left(\mathrm{~s}, 3 \mathrm{H},-\mathrm{CH}_{3}\right), 1.78\left(\mathrm{~s}, 3 \mathrm{H},-\mathrm{CH}_{3}\right) \mathrm{MS} \mathrm{m} / \mathrm{z}: 296(\mathrm{M}+)$, Anal. calcd. (\%) for: $\mathrm{C}_{16} \mathrm{H}_{16} \mathrm{~N}_{4} \mathrm{O}_{2}$ : C, 64.85; H, 5.44; N, 18.91; O, 10.80, found C, C, 64.79; H, 5.48; N, 18.93; O, 10.80

$\mathrm{N}$-(3-(4-methoxybenzyl)-2-oxo-2,3-dihydroimidazo[1,2-b]pyridazin-3-yl)acetamide (5g)

$\%$ Yield: $80 \%, \operatorname{mp}\left({ }^{\circ} \mathrm{C}\right): 164-168, \mathrm{IR}(\mathrm{KBr}) \mathrm{v}(\mathrm{cm}-1)$ : $3330(\mathrm{NH}) ; 2928(\mathrm{CH}), 1681(\mathrm{C}=\mathrm{O}),{ }^{1} \mathrm{H}$ NMR (DMSO) $\delta$ (ppm): 9.74(s,1H,NH), 7.21-7.48(m, 4H, ArH),7.19 (t, 2H, IPArH), 7.76(d, 1H, IPArH) $3.41\left(\mathrm{~s}, 2 \mathrm{H},-\mathrm{CH}_{2}\right), 2.89\left(\mathrm{~s}, 3 \mathrm{H},-\mathrm{OCH}_{3}\right), 2.28\left(\mathrm{~s}, 3 \mathrm{H},-\mathrm{CH}_{3}\right) \quad \mathrm{MS} \mathrm{m} / \mathrm{z}: 312(\mathrm{M}+)$, Anal. calcd. (\%) for: $\mathrm{C}_{16} \mathrm{H}_{16} \mathrm{~N}_{4} \mathrm{O}_{3}$ : C, 61.53; H, 5.16; N, 17.94; O, 15.37, found $\mathrm{C}, 61.57 ; \mathrm{H}, 5.13 ; \mathrm{N}, 17.97 ; \mathrm{O}, 15.34$

$\mathrm{N}$-(3-(4-aminobenzyl)-2-oxo-2,3-dihydroimidazo[1,2-b]pyridazin-3-yl)acetamide (5h)

$\%$ Yield: 78\%, mp: 158-162, IR(KBr) v (cm-1): 3330(NH), 3326(NH); 2928(CH), 1681(C=O), ${ }^{1} \mathrm{H}$ NMR (DMSO) $\delta(\mathrm{ppm}): 9.73(\mathrm{~s}, 1 \mathrm{H}, \mathrm{NH}), 7.12-7.52(\mathrm{~m}, 4 \mathrm{H}, \operatorname{ArH}), 7.22(\mathrm{t}, 2 \mathrm{H}, \mathrm{IPArH}), 7.81(\mathrm{~d}, 1 \mathrm{H}$, IPArH), 5.20(s,2H,- $\left.\mathrm{NH}_{2}\right), \quad 3.43\left(\mathrm{~s}, 2 \mathrm{H},-\mathrm{CH}_{2}\right), 2.24\left(\mathrm{~s}, 3 \mathrm{H},-\mathrm{CH}_{3}\right), \mathrm{MS} \mathrm{m} / \mathrm{z}: 297(\mathrm{M}+)$, Anal. calcd. (\%) for: $\mathrm{C}_{15} \mathrm{H}_{15} \mathrm{~N}_{5} \mathrm{O}_{2}: \mathrm{C}, 60.58 ; \mathrm{H}, 5.10 ; \mathrm{N}, 23.58 ; \mathrm{O}, 10.75$, found $\mathrm{C}, 60.60 ; \mathrm{H}, 5.09 ; \mathrm{N}, 23.56 ; \mathrm{O}, 10.76$.

$\mathrm{N}$-(3-(naphthalen-1-ylmethyl)-2-oxo-2,3-dihydroimidazo[1,2-b]pyridazin-3-yl)acetamide(5i)

$\%$ Yield: $74 \%, \operatorname{mp}\left({ }^{\mathrm{O}} \mathrm{C}\right): 182-184, \mathrm{IR}(\mathrm{KBr}) \mathrm{v}(\mathrm{cm}-1)$ : $3328(\mathrm{NH}), 2928(\mathrm{CH}), 1681(\mathrm{C}=\mathrm{O}),{ }^{1} \mathrm{H}$ NMR (DMSO) $\delta(\mathrm{ppm}):$ 9.71(s,1H,NH), 7.16-7.51(m, 7H, ArH), 7.18(t, 2H, IPArH), 7.95(d, 1H, IPArH) 3.43(s, $\left.2 \mathrm{H},-\mathrm{CH}_{2}\right), 2.2\left(\mathrm{~s}, 3 \mathrm{H},-\mathrm{CH}_{3}\right)$, MS m/z: 332(M+), Anal. calcd. (\%) for: $\mathrm{C}_{19} \mathrm{H}_{16} \mathrm{~N}_{4} \mathrm{O}_{2}: \mathrm{C}, 68.66 ; \mathrm{H}$, $4.85 ; \mathrm{N}, 16.86 ; \mathrm{O}, 9.63$, found $\mathrm{C}, \mathrm{C}, 68.69 ; \mathrm{H}, 4.88 ; \mathrm{N}, 16.81 ; \mathrm{O}, 9.63$

$\mathrm{N}$-(3-((1H-pyrrol-3-yl)methyl)-2-oxo-2,3-dihydroimidazo[1,2-b]pyridazin-3-yl)acetamide (5j)

$\%$ Yield: $76 \%, \mathrm{mp}\left({ }^{\circ} \mathrm{C}\right): 172-174, \operatorname{IR}(\mathrm{KBr}) \mathrm{v}(\mathrm{cm}-1): 3328(\mathrm{NH}), 3326(\mathrm{NH}), 2924(\mathrm{CH}), 1682(\mathrm{C}=\mathrm{O})$, ${ }^{1} \mathrm{H}$ NMR (DMSO) $\delta(\mathrm{ppm}): 9.69(\mathrm{~s}, 1 \mathrm{H}, \mathrm{NH}), 7.28(\mathrm{~d}, 1 \mathrm{H}, \mathrm{ArH}), 7.12(\mathrm{~d}, 1 \mathrm{H}, \mathrm{ArH}), 7.08(\mathrm{~d}, 1 \mathrm{H}, \mathrm{ArH})$, 7.24(t, 2H, IPArH), 7.92(d, 1H, IPArH), 4.8(s,1H,NH), 3.45(s, 2H,-CH $), 2.2\left(\mathrm{~s}, 3 \mathrm{H},-\mathrm{CH}_{3}\right), \mathrm{MS} \mathrm{m} / \mathrm{z}$ : 271(M+), Anal. calcd. (\%) for: $\mathrm{C}_{13} \mathrm{H}_{13} \mathrm{~N}_{5} \mathrm{O}_{2}: \mathrm{C}, 57.56 ; \mathrm{H}, 4.83 ; \mathrm{N}, 25.82 ; \mathrm{O}, 11.80$, found $\mathrm{C}, 57.52$; $\mathrm{H}, 4.90 ; \mathrm{N}, 25.84 ; \mathrm{O}, 11.82$

$\mathrm{N}$-(2-oxo-3-(pyridin-3-ylmethyl)-2,3-dihydroimidazo[1,2-b]pyridazin-3-yl)acetamide(5k)

\% Yield: $69 \%, \mathrm{mp}\left({ }^{\circ} \mathrm{C}\right): 244-250, \mathrm{IR}(\mathrm{KBr}) \mathrm{v}(\mathrm{cm}-1): 3330(\mathrm{NH}), 2924(\mathrm{CH}), 1682(\mathrm{C}=\mathrm{O}),{ }^{1} \mathrm{H}$ NMR (DMSO) $\delta(\mathrm{ppm}):$ 9.78(s,1H,NH), 7.67(dd, 2H, ArH), 7.22(dd, 2H, ArH), 7.24(t, 2H, IPArH), 7.92(d, 
Design, Synthesis Of N-(Substituted Imidazo [1,2-b]Pyridazine) Acetamides And Their Anti-

1H, IPArH), 3.41(s, $\left.2 \mathrm{H},-\mathrm{CH}_{2}\right), 2.2\left(\mathrm{~s}, 3 \mathrm{H},-\mathrm{CH}_{3}\right), \mathrm{MS} \mathrm{m} / \mathrm{z}$ : 283(M+), Anal. calcd. (\%) for: $\mathrm{C}_{14} \mathrm{H}_{13} \mathrm{~N}_{5} \mathrm{O}_{2}$ : C, 59.36; H, 4.63; N, 24.72; O, 11.30, found C, 59.34; H, 4.64; N, 24.70; O, 11.37

$\mathrm{N}$-(3-(furan-3-ylmethyl)-2-oxo-2,3-dihydroimidazo[1,2-b]pyridazin-3-yl)acetamide(5l)

\% Yield: $70 \%, \mathrm{mp}\left({ }^{\circ} \mathrm{C}\right): 210-212, \mathrm{IR}(\mathrm{KBr}) \mathrm{v}(\mathrm{cm}-1): 3328(\mathrm{NH}), 2925(\mathrm{CH}), 1681(\mathrm{C}=\mathrm{O}), 1155(\mathrm{C}-\mathrm{O})$, ${ }^{1} \mathrm{H}$ NMR (DMSO) $\delta$ (ppm): 9.72(s,1H,NH), 7.43(d, 2H, ArH), 7.25(t, 1H, ArH), 7.28(t, 2H, IPArH), 7.81(d, 1H, IPArH), 3.44(s, 2H,-CH $)_{2}, 2.1\left(\mathrm{~s}, 3 \mathrm{H},-\mathrm{CH}_{3}\right), \quad \mathrm{MS} \mathrm{m} / \mathrm{z}: 272(\mathrm{M}+)$, Anal. calcd. (\%) for: $\mathrm{C}_{13} \mathrm{H}_{12} \mathrm{~N}_{4} \mathrm{O}_{3}$ : C, 57.35; H, 4.44; N, 20.58; O, 17.63, found C, 57.40; H, 4.40; N, 20.60; O, 17.60

$\mathrm{N}$-(3-((1H-indol-3-yl)methyl)-2-oxo-2,3-dihydroimidazo[1,2-b]pyridazin-3-yl)acetamide(5m)

$\%$ Yield: $78 \%, \operatorname{mp}\left({ }^{\mathrm{O}} \mathrm{C}\right): 188-192, \mathrm{IR}(\mathrm{KBr}) \mathrm{v}(\mathrm{cm}-1)$ : 3345(indole $\left.\mathrm{NH}\right) ; 3234(\mathrm{NH}) ; 2932(\mathrm{CH})$, 1681(C=O), ${ }^{1} \mathrm{H}$ NMR (DMSO) $\delta(\mathrm{ppm}): 9.74(\mathrm{~s}, 1 \mathrm{H}, \mathrm{NH}), 7.28-7.40(\mathrm{~m}, 4 \mathrm{H}, \mathrm{ArH}), 7.12(\mathrm{~d}, 1 \mathrm{H}, \mathrm{ArH})$, 7.21(t, 2H, IPArH), 7.94(d, 1H, IPArH), 4.91(s,1H, NH), 3.44(s, 2H, $\left.-\mathrm{CH}_{2}\right), 2.1\left(\mathrm{~s}, 3 \mathrm{H},-\mathrm{CH}_{3}\right), \mathrm{MS} \mathrm{m} / \mathrm{z}$ : 321(M+), Anal. calcd. (\%) for: : $\mathrm{C}_{17} \mathrm{H}_{15} \mathrm{~N}_{5} \mathrm{O}_{2}: \mathrm{C}, 63.54 ; \mathrm{H}, 4.71 ; \mathrm{N}, 21.79 ; \mathrm{O}, 9.96$, found $\mathrm{C}, 63.50$; $\mathrm{H}, 4.74 ; \mathrm{N}, 21.82 ; \mathrm{O}, 9.99$

\section{$\mathrm{N}$-(3-((5-bromo-1H-indol-3-yl)methyl)-2-oxo-2,3-dihydroimidazo[1,2-b]pyridazin-3- yl)acetamide(5n)}

$\%$ Yield: $72 \%, \operatorname{mp}\left({ }^{\circ} \mathrm{C}\right): 204-210, \operatorname{IR}(\mathrm{KBr})$ v $(\mathrm{cm}-1)$ : 3345(indole $\left.\mathrm{NH}\right) ; 3234(\mathrm{NH}) ; 2929(\mathrm{CH})$, 1682(C=O), ${ }^{1} \mathrm{H}$ NMR (DMSO) $\delta(\mathrm{ppm}): 10.85(\mathrm{~s}, 1 \mathrm{H},-\mathrm{NH}), 9.61(\mathrm{~s}, 1 \mathrm{H},-\mathrm{NH}), 7.38(\mathrm{~d}, 2 \mathrm{H}, \quad \mathrm{ArH})$, 7.16(dd, 1H, ArH), 7.24(d, 1H, ArH) 7.19(t, 2H, IPArH), 7.85(d, 1H, IPArH), 3.40(s, 2H, - $\mathrm{CH}_{2}$ ), 2.12(s,3H,- $\mathrm{CH}_{3}$ ), MS m/z: 399(M+), Anal. calcd. (\%) for: $\mathrm{C}_{17} \mathrm{H}_{14} \mathrm{BrN}_{5} \mathrm{O}_{2}$ : C, 51.02; H, 3.53; $\mathrm{Br}$, $19.96 ; \mathrm{N}, 17.50 ; \mathrm{O}, 8.00$, found $\mathrm{C}, 51.07 ; \mathrm{H}, 3.49 ; \mathrm{Br}, 19.97 ; \mathrm{N}, 17.52 ; \mathrm{O}, 8.02$

\section{Conclusion}

In the present investigation a new series of $\mathrm{N}$-(3-substituted 2-oxo-2,3-dihydro imidazo $[1,2-b]$ pyridazine acetamides(5a-5n) synthesized and these compounds were characterized by FTIR, Mass and $1 \mathrm{H}$ NMR spectral data. All the title compounds were evaluated for the in vitro anti-proliferative activity on Braf v600E expressed cancer cell lines A375 and colo-205. All the compounds tested were found to be active and some compounds were found to be potent on the tested cell lines probably by inhibiting the BrafV600E kinase. The molecular docking studies on BafV600E kinase and the molecular properties predicted further supports mechanism of action of the compounds on BRafV600E kinase and hence these compounds could be considered as potential Braf kinase inhibitors.

\section{References}

[1] Miguel Garzó n and Paul W. Davies, A Direct Route into Fused Imidazo-diazines and Imidazo-pyridines Using Nucleophilic Nitrenoids in a Gold-Catalyzed Formal [3 + 2]-Dipolar Cycloaddition, Org. Lett, (2014), 16, 4850-4853.

[2] Vijay Jayaraman, Vinay Bulusu And Hemalatha Balaram, Crosstalk Between Purine Nucleotide Metabolism And Mitochondrial Pathways In Plasmodium Falciparum , Current Science, (2012) Vol. 102, No. 5, 10, ,757-766.

[3] Sachan Dinesh, Gangwar Shikha, Gangwar Bhavana, Sharma, Nidhi, Sharma Dileep,Biological Activities of Purine Analogues: A Review, Journal of Pharmaceutical and Scientific Innovation, (2012), 1 (2), 29-34.

[4] Francesco Di Virgilio, Purines, Purinergic Receptors, and Cancer, American Association for Cancer Research. October 22, 2012; DOI: 10.1158/0008-5472.CAN-12-1600,5441-5447.

[5] Richa Goel, Vijay Luxami and Kamaldeep Paul, Synthetic approaches and functionalizations of imidazo[1,2-a]pyrimidines: an overview of the decade, RSC Adv., (2015),5, 81608-81637.

[6] Avik Kumar Bagdi, Sougata Santra, Kamarul Monir and Alakananda Hajra, Synthesis of imidazo[1,2-a]pyridines: a decade update, Chem. Commun., (2015),51, 1555-1575.

[7] Reviews: (a) Regan. A. C. In Comprehensive Heterocyclic Chemistry III; Katritzky, A. R., Ramsden, A. C., Scriven, E. F. V.,Taylor, R. J. K., Eds.; Pergamon-Elsevier Science: Oxford, (2008), Vol.11, 551-587.

[8] Claire Le Manach, Tanya Paquet, Diego Gonzàlez Cabrera, Yassir Younis, Dale Taylor, Lubbe Wiesner, Nina Lawrence, Sylva Schwager, David Waterson, Michael J. Witty, Sergio Wittlin, Leslie J. Street, and Kelly Chibale , Medicinal Chemistry Optimization of Antiplasmodial Imidazopyridazine Hits from High Throughput Screening of a SoftFocus Kinase Library: Part 2, J. Med. Chem., (2014), 57 (21), pp 8839-8848.

[9] WO 2008/079880 A1 (Alcon Research, Ltd.) relates to 6-aminoimidazo[1,2-b]pyridazine analogues as Rho-kinase inhibitors for the treatment of glaucoma and ocular hypertension.

[10] R. Moslin, D. Gardner, J. Santella, Y. Zhang, J. V. Duncia, C. Liu, J. Lin, J. S. Tokarski, J. Strnad, D. Pedicord, J. Chen, Y. Blat, A. Zupa-Fernandez, L. Cheng, H. Sun, C. Chaudhry, C. Huang, C. D'Arienzo, J. S. Sack, J. K. Muckelbauer, C. Chang, J. Tredup, D. Xie, N. Aranibar, J. R. Burke, P. H. Carter and D. S. Weinstein, Identification of imidazo[1,2- $b]$ pyridazine TYK2 pseudokinase ligands as potent and selective allosteric inhibitors of TYK2 signalling, Med Chem Com, (2017), 8(4), 700-712

[11] WO 2008/072682 A1 (Daiichi Sankyo Company, Limited) relate to imidazo[1,2-b]pyridazine derivative which has an action of inhibiting TNF-alpha production, exerts an effect in a pathological model of inflammatory disease and/or auto-immune disease.

[12] Bullock AN, Debreczeni JE, Fedorov OY, Nelson A, Marsden BD, Knapp S. Structural basis of inhibitor specificity of the human protooncogene proviral insertion site in moloney murine leukemia virus (PIM-1) kinase. J. Med. Chem., (2005), 48, 7604-7614

[13] Julen Oyarzabal, Natasha Zarich, María Isabel Albarran, Irene Palacios, Manuel Urbano-Cuadrado, Genoveva Mateos, Isabel Reymundo, Obdulia Rabal, Antonio Salgado, Ana Corrionero, Jesús Fominaya, Joaquin Pastor, and James R. Bischoff, Discovery of Mitogen-Activated Protein Kinase-Interacting Kinase 1 Inhibitors by a Comprehensive Fragment-Oriented Virtual Screening 
Approach", and discloses, inter alia, in Table 1, some specific imidazo[1,2-b]pyridazines as compounds identified as MKNK-1 inhibitors, J. Med. Chem., (2010), 53, 6618-6628.

[14] Konicek BW ${ }^{1}$, Stephens JR, McNulty AM, Robichaud N, Peery RB, Dumstorf CA, Dowless MS, Iversen PW, Parsons S, Ellis KE, McCann DJ, Pelletier J, Furic L, Yingling JM, Stancato LF, Sonenberg N, Graff JR. Therapeutic inhibition of MAP kinase interacting kinase blocks eukaryotic initiation factor 4E phosphorylation and suppresses outgrowth of experimental lung mestastases, Cancer Res Mar. 1, (2011), 71, 1849-1857.

[15] Deborah T. Leicht, Vitaly Balan, Alexander Kaplun, Vinita Singh-Gupta, Ludmila Kaplun, Melissa Dobson, and Guri Tzivion Raf Kinases: Function, Regulation and Role in Human Cancer, Biochim Biophys Acta. (2007), 1773(8): 1196-1212.

[16] K. Sruthi, M. Sumakanth, Mahendra Kumar CB, K Naresh, Nitrogen Bridged Imidazo Pyrimidine Acetamides: Synthesis, Molecular Docking, Toxicity Prediction And Anti-Proliferative Studies, Eur J Bio med Phar. Sci., (2017),4( 5), , 313-320.

[17] Morris, G. M., Huey, R., Lindstrom, W., Sanner, M. F., Belew, R. K., Goodsell Ds, Olson AJ. Autodock4 and AutoDockTools4: automated docking with selective receptor flexiblity. J. Comp. Chem (2009), 16, 2785-91 